$$
\begin{gathered}
\text { 갯벌에서 분리한 유기염소계 살충제 Endosulfan } \\
\text { 분해 세균의 특성 } \\
\text { 박미은·김영목'정용현* } \\
\text { 부경대학교 생태공학과, }{ }^{1}{ }^{*} \text { 경대학교 식품공학과 }
\end{gathered}
$$

\title{
Characterization of Organochlorine Insecticide Endosulfan-Degrading Bacterium Isolated from Seaside Sediment
}

\author{
Mi-Eun Park, Young-Mog Kim ${ }^{1}$ and Yong-Hyun Chung* \\ Department of Ecological Engineering, Pukyong National University, \\ Busan 608-737, Korea \\ ${ }^{1}$ Department of Food Science and Technology, Pukyong National University, \\ Busan 608-737, Korea
}

An endosulfan degrading bacterial strain, K-1321, was isolated by endosulfan-enrichment culture from a seaside sediment collected at Dadaepo Beach, Busan, Korea. The strain was identified as a Serratia sp. based on the results of morphological, biochemical and 16S rDNA homology analyses. Serratia sp. K-1321 was able to completely degrade $50 \mathrm{ppm}$ endosulfan in culture media and soil within 6 weeks at $25^{\circ} \mathrm{C}$. GC/MS analysis revealed that endosulfan diol was an intermediate of the bacterial endosulfan degradation. Considering the above results, we concluded that Serratia sp. K-1321 utilized endosulfan as a carbon source and metabolized endosulfan via a less toxic pathway, such as the formation of endosulfan diol as an intermediate.

Key words: Bioremediation, Endosulfan, Organochlorine, Seaside sediment

서 론

현대 농업에서 농약은 병충·해충 및 잡초 등을 방제함으로 서 농산물의 질적.양적인 소실을 방지하고, 노동력 부족을 대체하여 안정적인 농산물의 공급을 가능하게 하였다. 농약은 그 특성 상 생물독성과 환경 및 생물체 내 잔류성을 가지며, 일부 농약의 경우 잔류성과 독성이 강하며 자연적으로 잘 분해가 되지 않아 많은 토양오염을 야기하였다 (Shin et al., 2008). 특히 유기염소계 살충제는 강한 독성을 가진 농약으로, 과거에는 널리 사용되었으나, 부작용이 많고 환경 및 체내에 오랫동안 잔류하는 특성이 있어 현재에는 몇몇 약제를 제외하 고 사용이 금지되었다 (Shin et al., 2008; Usha and Harikrishnan, 2004).

Endosulfan $(6,7,8,9,10,10$-hexachloro-1,5,5a,6,9,9a-hexahydro -6,9 -methano-2,4,3-benzodioxathiepine-3-oxide)은 비침투성 유 기염소계 농약으로서, 일반적으로 입체이성질체인 $a$ -endosulfan과 $\beta$-endosulfan이 약 7:3으로 혼합된 약제를 말한 다 (Siddique et al., 2003; Lee et al., 2006; Kim et al., 2008). $\mathrm{DDT}$, aldrin 등 기존의 유기염소계 농약을 대체하여 전 세계적 으로 사용되어 왔으며 (Usha and Harikrishnan, 2004), 현재 우리나라에서 가장 많이 사용되고 있는 유기염소계 살충제이 다. 그러나 endosulfan은 내분비계 교란물질로 보고되어 있으 며, 인축 및 어류 독성으로 인해 UNEP (United Nations

\footnotetext{
*Corresponding author: chungyh@pknu.ac.kr
}

Environment Programme)에서 독성물질로 (Guerin, 2001), WHO (World Health Organization)에는 Category II, EU 및 US EPA (US Environmental Protection Agency)에는 Catergory I B 물질로 분류되어 있다 (Usha and Harikrishnan, 2004). Endosulfan에 중독되면 신경계 과잉 자극, 반복적 경련, 심혈관 허탈, 호흡부전, 두통, 흉통 등의 증상을 나타내며, 사망에까지 이르는 것으로 알려져 있다 (Kim et al., 2004a; Park et al., 2008; Beauvais et al., 2010; Silva and Beauvais, 2010; Silva and Carr, 2010). 또한, endosulfan은 급성독성 뿐만 아니라 만성독성에 의한 위해성 역시 높으며, 포유류에 대한 생식독 성 (gonadal toxicity), 유전독성 (genotoxicity), 신경독성 (neurotoxicity) 등을 유발할 수 있는 것으로 보고되어 있으며, $1 \mathrm{ppb} 1 \mathrm{ppm}$ 의 농도에서 인간의 적혈구, 혈소판 및 헤모글로 빈을 파괴한다는 연구가 있다 (Chaudhuri et al., 1999; Usha and Harikrishnan, 2004; Kim et al., 2004a; Park et al., 2008).

Endosulfan은 효과에 비해 부작용이 많고 환경 및 먹이연쇄 에 의한 체내 축적과 이에 따른 인체 부작용 때문에 현재에는 그 사용이 제한적으로 허용되고 있다 (Usha and Harikrishnan, 2004). 그러나 최근까지도 토양, 지하수, 하천, 해수, 대기 등의 환경과 식품에서 자주 검출되고 있어 (Kim et al., 2000; Chung et al., 2001; Laabs et al., 2002; Harner et al., 2005; Lo'pez-Blanco et al., 2005; Kim et al., 2007; Ha et al., 2009; Park et al., 2009) 인체에 대하여 직·간접적으로 위해성을 가질 수 있어 문제가 되고 있다. 
따라서 본 연구는 유기독성 물질로서 환경 중에 잔류하여 토양 및 수질 오염을 유발하는 endosulfan을 효과적으로 분해 할 수 있는 미생물을 이용한 친환경적인 분해방법을 개발하기 위하여 endosulfan에 대한 내성이 높고 endosulfan 분해력이 높은 미생물의 분리를 시도하였고 그 후 분리된 균을 사용하 여 endosulfan의 분해 특성을 조사하였다.

\section{재료 및 방법}

실험 재료

본 연구에 사용한 endosulfan (순도 $99.0 \%$ )의 표준품은 Augsburg사 (독일)에서 구입하였으며, 분해균 배양에 사용한 endosulfan은 (주경농의 경농 지오릭스 유제 (endosulfan 순도 $35 \%)$ 를 구입하여 사용하였다. 그 외에 시험에 사용된 시약은 분석용의 특급시약을 구매하여 사용하였다.

시료

Endosulfan 분해 균주의 분리를 위해 2010년 5월에 경북 청도군 일대의 endosulfan이 많이 사용되는 과수원과 낙동강 하구 다대포 해수욕장 인근 갯벌에서 토양 및 저질 시료를 채취하였다.

\section{균의 분리 및 배양}

Endosulfan 분해 능력이 우수한 균을 선발하기 위해 집식배 양을 실시하였다. 접종원은 Shin et al. (2008)의 방법을 참고하 여 채취한 시료 $10 \mathrm{~g}$ 을 $100 \mathrm{~mL}$ 의 LB (Luria-Bertani media, Difco., USA) 배지에 넣고 $25^{\circ} \mathrm{C}$ 에서 $120 \mathrm{rpm}$ 으로 24 시간 진탕 배양 후 다시 1 시간 동안 정치하여 이 상등액 $10 \mathrm{~mL}$ 를 접종액 으로 사용하였다. 배양 배지는 Fujii et al. (2000) 및 Kim et al. (2004b)의 방법을 참고하여 탄소원이 없는 YNB (Yeast nitrogen base without amino acid, Difco. USA) 배지 $100 \mathrm{~mL}$ 에 탄소원으로서 $100 \mathrm{ppm}$ endosulfan을 첨가한 집식배지에 접종 액을 가하여 $25^{\circ} \mathrm{C}, 120 \mathrm{rpm}$ 으로 1 주 간격으로 3 차례 계대를 거치며 집식배양을 하였으며, 최종적으로 $100 \mathrm{ppm}$ 의 endosulfan을 첨가한 $\mathrm{YNB}$ 한천 배지 (상기 $\mathrm{YNB}$ 배지에 $1.5 \%$ 한천을 가한 배지)에 도말하여 단일 균주를 분리하였다.

Table 1. GC/MS operating conditions for endosulfan analysis

\begin{tabular}{|c|c|}
\hline GC/MS & Shimazu (GC 2010 plus/ GC-MS 2010) \\
\hline Column & $\begin{array}{l}\text { DB-5 (CBP1-S25-050) } \\
\text { (Length } 30 \mathrm{~m} \times \text { I.D. } 0.32 \mathrm{~mm} \\
\text { Film thickness } 0.25 \mu \mathrm{m} \text { ) }\end{array}$ \\
\hline Injector & Splitless \\
\hline Injection volume & $1 \mu \mathrm{L}$ \\
\hline Carrier gas & $\mathrm{He} 1.14 \mathrm{~mL} / \mathrm{min}$ \\
\hline Aux temp. & $250^{\circ} \mathrm{C}$ \\
\hline $\begin{array}{l}\text { Oven temp. } \\
\text { program }\end{array}$ & $\begin{array}{l}100^{\circ} \mathrm{C} \text { for } 2 \mathrm{~min} \\
100-300^{\circ} \mathrm{C} \text { at } 5^{\circ} \mathrm{C} / \mathrm{min} \\
300^{\circ} \mathrm{C} \text { for } 3 \mathrm{~min}\end{array}$ \\
\hline $\begin{array}{l}\text { lon source temp } \\
\text { Quadrupole temp }\end{array}$ & $\begin{array}{l}200^{\circ} \mathrm{C} \\
220^{\circ} \mathrm{C}\end{array}$ \\
\hline \multirow{2}{*}{ Detection } & \begin{tabular}{ll}
\multirow{2}{*}{ Qualitation } & Selective ion monitoring (SIM), \\
& Ref. ion $\mathrm{m} / \mathrm{z}: 241,207,195$
\end{tabular} \\
\hline & $\begin{array}{ll}\text { Quantitation } & \text { Full scan, } \\
\mathrm{m} / \mathrm{z}: 50-500, \text { scan speed } 1,000\end{array}$ \\
\hline
\end{tabular}

Endosulfan 잔류량 측정 및 분해산물 분석

Endosulfan을 첨가한 $\mathrm{YNB}$ 한천배지에서 분리된 균들의 endosulfan 분해능 측정 및 분해산물 분석을 위해 $100 \mathrm{ppm}$ 의 endosulfan이 첨가된 1/10 LB 배지 (Shin et al., 2008)에서 1주 이상 진탕배양 하였다. 배양 후 배양액에 잔류하는 endosulfan 을 분석하기 위하여 배양액에 2 배량의 n-hexane을 가하여 3 분 간 vortex mixer로 진탕한 후 $\mathrm{n}$-hexane 층을 $0.20 \mu \mathrm{m}$ Cellulose Acetate filter (Advantec MFS Inc., Dublin, CA)로 걸러 GC/MS (Shimadzu GC 2010 plus/ GC-MS 2010)로 분석하였으며, 분석 조건은 Table 1 과 같다.

정성분석을 위한 endosulfan 표준품 및 분해산물의 $\mathrm{GC} / \mathrm{MS}$ 분석 결과, $\alpha$-endosulfan $(\mathrm{m} / \mathrm{z}$ : 404)은 약 $25.97 \mathrm{~min}, \beta$ -endosulfan (m/z : 404)은 약 $28.07 \mathrm{~min}$, endosulfan sulfate $(\mathrm{m} / \mathrm{z}$ : 420) 및 endosulfan diol (m/z : 358)은 각각 약 $35.45 \mathrm{~min}$ 과 약 $27.95 \mathrm{~min}$ 에서 관측되었다. 이를 바탕으로 시간에 따른 peak 면적의 증가를 보인 peak에 대하여 endosulfan 분해 산물 의 peak 및 ion spectrum과 대조하여 각 단일 균주에 의한 endosulfan 분해 산물을 검색하였다.

\section{분리균의 동정}

분리균은 형태학적 및 생화학적 분류와 $16 \mathrm{~S} \mathrm{rDNA}$ 염기서 열 분석을 통하여 동정하였다. Endosulfan 분해 분리균의 생화 학적 특성 검사 및 동정은 그람 염색 후 그 결과에 따라 BioMerieux Vitek Gram negative identification card (GNI+)를 사용하여 분석하였으며, 그람 음성균 동정 카드 software 버전 R10.01 (BioMerieux, USA)을 사용하여 동정하여 그 결과를 Bergey's Manual of Systematic Bacteriology Vol. 1 (Krieg and Holt, 1984)에 따라 확인하였다. Chromosomal DNA의 추출은 Berns and Thomas (1965) 가 기술한 일반적인 방법에 따라 행하였으며, DNA의 분리 및 조작에 사용한 시약 및 PCR kit들 은 주로 Takara사 (Seoul, Korea)의 것을 사용하였다. PCR 반응 에 사용된 DNA oligonucleotide는 Bioneer사 (Daejeon, Korea) 에 의뢰하여 합성하였다. PCR 반응에 사용한 primer는 Dunbar et al. (2000)의 문헌에 따라 제작하였으며 (27F, 5'-GTTT GGATCCTGGCTCAG-3'; 1492R, 5'-AAGGAGGGGA TCCA GCC-3'), PCR 반응 조성은 DNA template에 27F primer, 1492R primer, $10 \times$ buffer, $10 \mathrm{mM}$ dNTP mixture, $5 \mathrm{X}$ band (5XBD), EF-Taq polymerase를 첨가하여 총 $50 \mu \mathrm{L}$ 의 혼합물로 수행하 였다. 혼합한 반응액은 $94^{\circ} \mathrm{C}$ 에서 2 분간 변성시켰다. 이를 $52^{\circ} \mathrm{C}$ 에서 2 분간 annealing 한 후 $72^{\circ} \mathrm{C}$ 에서 2 분간 polymerization 시켰 다. 다시 $94^{\circ} \mathrm{C}$ 에서 2 분, $60^{\circ} \mathrm{C}$ 에서 2 분, $72^{\circ} \mathrm{C}$ 에서 2 분의 cycle을 20 회 반복하여 시행하였다. 염기서열의 상동성 검색은 Ribosomal database (http://www.ncbi.nlm.nih.gov/ BLAST) 를 통하여 실시하였다.

Endosulfan 농도에 따른 분리균의 endosulfan 분해 특성 분리한 균주의 endosulfan 분해 한계를 알아보기 위해 농도 가 각각 $10,20,50,100,200,500,1,000 \mathrm{ppm}$ 의 endosulfan을 함유하는 $\mathrm{YNB}$ 배지를 조제하였다. 그 후 분리균을 접종하여 $25^{\circ} \mathrm{C}$ 에서 $120 \mathrm{rpm}$ 조건으로 진탕 배양하며 배지에 잔존하는 
endosulfan을 시간별로 관찰하였다.

보조 탄소원 농도에 따른 분리균의 endosulfan 분해 특성

보조 탄소원의 농도에 따른 endosulfan 분해 정도를 알아보 기 위해 $100 \mathrm{ppm}$ 의 endosulfan과 보조 탄소원인 yeast extract의 농도가 각각 $0.01 \%, 0.05 \%, 0.1 \%, 0.5 \%$ 가 되도록 첨가하여 $\mathrm{YNB}$ 배지를 조제하였다. 각각의 배지에 분리균을 접종하여 $25^{\circ} \mathrm{C}$ 에서 진탕 배양하면서 시간에 따른 endosulfan의 잔류량 을 분석하였다.

Table 2. Endosulfan dissipation ratio by strains isolated from enrichment culture

\begin{tabular}{|c|c|c|c|c|c|}
\hline $\begin{array}{l}\text { Strain } \\
\text { No. }\end{array}$ & $\begin{array}{l}\text { Remaining } \\
\text { rate }(\%)\end{array}$ & $\begin{array}{c}\text { Degradation } \\
\text { product }\end{array}$ & $\begin{array}{c}\text { Strain } \\
\text { No. }\end{array}$ & $\begin{array}{l}\text { Remainin } \\
\text { rate }(\%)\end{array}$ & $\begin{array}{l}\text { Degradation } \\
\text { product }\end{array}$ \\
\hline K-1120 & 46.4 & $\begin{array}{l}\text { endosulfan } \\
\text { sulfate }\end{array}$ & S-120 & 104.3 & N. D. \\
\hline $\mathrm{K}-1131$ & 91.5 & N. D. & S-131 & 107.0 & N. D. \\
\hline K-1132 & 92.8 & N. D. & S-132 & 129.4 & N. D. \\
\hline K 1220 & 98.0 & N. D. & S-220 & 120.8 & N. D. \\
\hline K-1321 & 19.8 & $\begin{array}{l}\text { endosulfan } \\
\text { diol }\end{array}$ & S-321 & 113.2 & N. D. \\
\hline K-1322 & 94.8 & N. D. & S-322 & 85.2 & N. D. \\
\hline K-1331 & 56.4 & $\begin{array}{l}\text { endosulfan } \\
\text { diol }\end{array}$ & S-331 & 101.1 & N. D. \\
\hline K-1332 & 43.6 & $\begin{array}{l}\text { endosulfan } \\
\text { sulfate }\end{array}$ & S-332 & 85.3 & N. D. \\
\hline K-2120 & 31.2 & $\begin{array}{c}\text { endosulfan } \\
\text { diol }\end{array}$ & $\mathrm{N}-1120$ & 75.7 & $\begin{array}{l}\text { endosulfan } \\
\text { sulfate }\end{array}$ \\
\hline K-2130 & 34.7 & $\begin{array}{l}\text { endosulfan } \\
\text { sulfate }\end{array}$ & $\mathrm{N}-1131$ & 78.8 & $\begin{array}{l}\text { endosulfan } \\
\text { sulfate }\end{array}$ \\
\hline $\mathrm{K}-2220$ & 89.0 & N. D. & $\mathrm{N}-1132$ & 98.2 & N. D. \\
\hline K-2321 & 72.3 & $\begin{array}{l}\text { endosulfan } \\
\text { sulfate }\end{array}$ & $\mathrm{N}-1220$ & 103.3 & N. D. \\
\hline $\mathrm{K}-2322$ & 40.2 & $\begin{array}{l}\text { endosulfan } \\
\text { sulfate }\end{array}$ & $\mathrm{N}-1321$ & 83.2 & N. D. \\
\hline $\mathrm{K}-2331$ & 30.1 & $\begin{array}{c}\text { endosulfan } \\
\text { diol }\end{array}$ & $\mathrm{N}-1322$ & 84.5 & N. D. \\
\hline K-2332 & 63.7 & $\begin{array}{l}\text { endosulfan } \\
\text { sulfate }\end{array}$ & 1331 & 107.7 & N. \\
\hline $\mathrm{K}-2333$ & 70.5 & $\begin{array}{l}\text { endosulfan } \\
\text { sulfate }\end{array}$ & $\mathrm{N}-1332$ & 90.0 & N. D. \\
\hline
\end{tabular}

Endosulfan 분해균에 의한 토양에서의 endosulfan 분해 특성

토양에서의 분리균의 endosulfan 분해능을 알아보기 위해 토양 실험을 실시하였다. 토양 실험에 사용한 토양은 부산시 기장군에 위치한 밭에서 채취한 토양을 $2 \mathrm{~mm}$ 체로 통과시킨 후 $110^{\circ} \mathrm{C}, 15$ 기압에서 30 분 동안 고압증기멸균을 3 번 반복하여 멸균시켜 사용하였다. Endosulfan의 토양에의 흡착 및 휘발 등의 요건을 고려하여 $100 \mathrm{~g}$ 의 토양에 endosulfan의 농도가 각각 50 , $100,200,500 \mathrm{ppm}$ 이 되도록 임의 오염시켰다. 그 후 LB 배지에 배양한 endosulfan 분해균 배양액을 $20 \mathrm{~mL}$ 씩 주입하였으며, 유사한 조건을 조성하기 위해 대조구 (비접종구)에는 같은 양의 멸균된 LB 배지를 가하였다. a-Endosulfan의 경우 증기압이 $4.0 \times 10^{-4} \mathrm{~Pa}$ 로 휘발성이 강하여 토양 중에서 빨리 제거되는
경향을 보이므로 (Guerin, 2001), 휘발에 의한 잔류 endosulfan 농도의 오차를 줄이기 위해 각 실험구의 입구를 실리콘스토퍼 를 이용하여 막았다. 토양 실험 장치는 $25^{\circ} \mathrm{C}$ 에서 관찰하면서 토양 중에 잔류하는 endosulfan 변화를 측정하였다.

$$
\text { 결과 및 고찰 }
$$

Endosulfan 분해균의 분리

Endosulfan을 함유한 고체 평판배지에서 총 32 주의 단일 균주를 분리하였으며, 이 중 12주의 균주가 endosulfan 분해능 을 보였다. Endosulfan sulfate는 ensoaulfan의 분해산물 중 하나 로, 그 독성이 모화합물인 endosulfan과 비슷하며, 환경 및 체내 잔류성은 endosulfan보다 더 큰 것으로 알려져 있다 (Rao and Murty, 1980; Shin et al., 2008; Cho, 2010) 따라서 분해산물 로서 endosulfan sulfate를 생성하지 않는 균주 중 상대적으로 endosulfan의 분해능이 뛰어난 균주를 endosulfan 분해균으로 선정하였다. 그 결과 본 연구에서 분리된 균들 중에서 endosulfan 분해능이 가장 뛰어나고 endosulfan sulfate를 생성 하지 않는 K-1321을 endosulfan bioremediation 연구를 위한 균주로 최종 선발하고 이 후 연구를 진행하였다 (Table 2).

Table 3. Biochemical properties of the isolated strain K-132

\begin{tabular}{|c|c|c|}
\hline $\begin{array}{c}\text { Medium } \\
\text { Abbreviation }\end{array}$ & Principal component & Result \\
\hline DP3 & 2,2,4'-Trichloro-2'-Hydroxydiphenylether & + \\
\hline OFG & Glucose & + \\
\hline GC & Tryptophan & + \\
\hline ACE & Acetamide & - \\
\hline ESC & Esculin & + \\
\hline PLI & Indoxyl- $\beta$-D-Glucoside & + \\
\hline URE & Urea & - \\
\hline $\mathrm{CIT}$ & Citrate & + \\
\hline MAL & Malonate & - \\
\hline TDA & Tryptophan & - \\
\hline PXB & Polymyxin B & + \\
\hline LAC & Lactose & - \\
\hline MLT & Maltose & + \\
\hline MAN & Mannitol & + \\
\hline$X Y L$ & Xylose & - \\
\hline RAF & Raffinos & - \\
\hline SOR & Sorbitol & - \\
\hline SUC & Sucrose & + \\
\hline INO & Inositol & + \\
\hline ADO & Adonitol & + \\
\hline $\mathrm{COU}$ & $\rho$-coumaric & + \\
\hline $\mathrm{H} 2 \mathrm{~S}$ & Sodium Thiosulfate, Lactate, Ferrous Sulfate & - \\
\hline ONP & O-Nitrophenyl- $\beta-D-G a l a c t o p y r a n o s i d e$ & - \\
\hline RHA & Rhamanose & - \\
\hline ARA & L-Arabinose & - \\
\hline GLU & glucose & + \\
\hline ARG & Arginine & - \\
\hline LYS & Lysine & + \\
\hline ORN & Ornithine & + \\
\hline OXI & Oxidase & - \\
\hline
\end{tabular}


Table 4. 16S rDNA sequences $(1,420 \mathrm{bp})$ and identification of the isolation strain $\mathrm{K}-1321$ by homology search based on $16 \mathrm{~S}$ rDNA

\begin{tabular}{|c|c|c|c|c|c|c|c|}
\hline 1 & ATGCAAGTCG & AGCGGTAGCA & CAGGGGAGCT & TGCTCCCTGG & GTGACGAGCG & GCGGACGGGT & $\overline{60}$ \\
\hline 61 & GAGTAATGTC & TGGGAAACTG & CCTGATGGAG & GGGGATAACT & ACTGGAAACG & GTAGCTAATA & 120 \\
\hline 121 & CCGCATAACG & TCGCAAGACC & AAAGAGGGGG & ACCTTCGGGC & СTCTTGCCAT & CAGATGTGCC & 180 \\
\hline 181 & CAGATGGGAT & TAGCTAGTAG & GTGGGGTAAT & GGCTCACCTA & GGCGACGATC & CCTAGCTGGT & 240 \\
\hline 241 & CTGAGAGGAT & GACCAGCCAC & ACTGGAACTG & AGACACGGTC & CAGACTCCTA & CGGGAGGCAG & 300 \\
\hline 301 & CAGTGGGGAA & TATTGCACAA & TGGGCGCAAG & CCTGATGCAG & CCATGCCGCG & TGTGTGAAGA & 360 \\
\hline 361 & AGGCCTTCGG & GTTGTAAAGC & ACTTTCAGCG & AGGAGGAAGG & TGGTGAGCTT & AAATACGTTC & 420 \\
\hline 421 & ATCAATTGAC & GTTACTCGCA & GAAGAAGCAC & CCGGCTAACT & CCGTGCCAGC & AGCCGCGGTA & 480 \\
\hline 481 & ATACGGAGGG & TGCAAGCGTT & AATCGGAAAT & TACTGGGCGT & AAAGCGCACG & CAGGCGGTTT & 540 \\
\hline 541 & GTTAAGTCAG & ATGTGAAATC & CCCGGGCTCA & ACCTGGGAAC & TGCATTTGAA & ACTGGCAAGC & 60 \\
\hline 601 & TAGAGTCTCG & TAGAGGGGGG & TAGAATTCCA & GGTGTAGCGG & TGAAATGCGT & AGAGATCTGG & 660 \\
\hline 661 & AGGAATACCG & GTGGCGAAGG & CGGCCCCCTG & GACGAAGACT & GACGCTCAGG & TGCGAAAGCG & 720 \\
\hline 721 & TGGGGAGCAA & ACAGGATTAG & ATACCCTGGT & AGTCCACGCT & GTAAACGATG & TCGATTTGGA & 78 \\
\hline 781 & GGTTGTGCCC & TTGAGGCGTG & GCTTCCGGAG & CTAACGCGTT & AAATCGACCG & CCTGGGGAGT & 84 \\
\hline 841 & ACGGCCGCAA & GGTTAAAACT & CAAATGAATT & GACGGGGGCC & CGCACAAGCG & GTGGAGCATG & 90 \\
\hline 901 & TGGTTTAATT & CGATGCAACG & CGAAGAACCT & САССТАСТСТ & TGACATCCAG & AGAAC & 960 \\
\hline 961 & AGAGATGCTT & TGGTGCCTTC & GGGAACTCTG & AGACAGGTGC & TGCATGGCTG & TCGTCAGCTC & 1020 \\
\hline 1021 & GTGTTGTGAA & ATGTTGGGTT & AAGTCCCGCA & ACGAGCGCAA & СССТТАТССТ & TTGTTGCCAG & 108 \\
\hline 1081 & CGGTTCGGCC & GGGAACTCAA & AGGAGACTGC & CAGTGATAAA & CTGGAGGAAG & GTGGGGATGA & 114 \\
\hline 1141 & CGTCAAGTCA & TCATGGCCCT & TACGAGTAGG & GCTACACACG & TGCTACAATG & GCGTATACAA & 1200 \\
\hline 1201 & AGAGAAGCGA & CCTCGCGAGA & GCAAGCGGAC & СТСATAAAGT & ACGTCGTAGT & CCGGATTGGA & 1260 \\
\hline 1261 & GTCTGCAACT & CGACTCCATG & AAGTCGGAAT & CGCTAGTAAT & CGTAGATCAG & AATGCTACGG & 132 \\
\hline 1321 & TGAATACGTT & CCCGGGCCTT & GTACACACCG & CCCGTCACAC & CATGGGAGTG & GGTTGCAAAA & 1380 \\
\hline 1381 & GAAGTAGGTA & GCTTAACCTC & GGGAGGGCGC & TTACCACTTT & 1420 & & \\
\hline \multicolumn{5}{|c|}{ Reference (accession no.) } & \multicolumn{2}{|c|}{ Identity (\%) } & \\
\hline \multirow{3}{*}{\multicolumn{4}{|c|}{$\begin{array}{l}\text { Serratia marcescens KRED AB061685 } \\
\text { Serratia nematodiphila DZ0503SBS1 EU036987 } \\
\text { Serratia marcescens DSM } 30121 \text { AJ233431 }\end{array}$}} & & \multicolumn{2}{|c|}{96} & \\
\hline & & & & & \multicolumn{2}{|c|}{$\begin{array}{l}96 \\
95\end{array}$} & \\
\hline & & & & & \multicolumn{2}{|c|}{95} & \\
\hline
\end{tabular}

The sequence data was analyzed via ribosomal database (htt://www.ncbi. nlm.nih.gov/BLAST).

Endosulfan 분해균의 동정

선발된 분리균주 K-1321은 낙동강 하구 다대포 해수욕장 인근의 갯벌에서 채취한 시료에서 분리된 균주로 그람 염색에 서 그람 음성의 단간균으로 조사되었다. 분리 균주의 생화학 적 특성은 Table 3 에 나타내었으며, 분리균의 $16 \mathrm{~S} \mathrm{rDNA}$ 염기 서열의 상동성 분석 결과, 분리균 K-1321은 Serratia marcescens KRED (accession no. AB061685) 및 $S$. nematodiphila DZ0503SBS1 (accession no. EU036987)의 16S rDNA와 96\%, S. marcescens DSM 30121 (accession no. $\mathrm{AJ} 233431)$ 등의 Serratia 속에 속하는 균주들과 $95 \%$ 의 상동성 을 나타내었다 (Table 4). 이러한 결과로부터 분리 선발된 K-1321 균주는 Serratia sp.에 속하는 것으로 판단되어 Serratia sp. K-1321로 명명하였다.

Endosulfan 농도에 따른 분리균의 endosulfan 분해 특성 $\mathrm{NB}$ 배지에서 endosulfan의 농도에 따른 분리균 K-1321의 분해능을 측정하였다. 그 결과 endosulfan의 초기 농도가 10 $\mathrm{ppm}$ 로 첨가한 $\mathrm{YNB}$ 배지의 경우, 배양 4 주 만에 $100 \%$ 분해되 었으며, $50 \mathrm{ppm}$ 의 endosulfan을 함유한 배지의 경우에도 배양 6주에 endosulfan이 $100 \%$ 분해되었다. 초기 농도 $100 \mathrm{ppm}$ 및 $200 \mathrm{ppm}$ 의 endosulfan을 함유한 배지의 경우, 관찰 기간 동안 각각 약 $82 \%, 65 \%$ 의 endosulfan 분해율을 보였으며, 500 $\mathrm{ppm}$ 의 경우 배양 기간 동안 약 $30 \%$ 의 endosulfan 분해율을 보여 endosulfan이 느리게 분해되는 양상을 보였다. $1,000 \mathrm{ppm}$ 을 함유한 배지의 경우에는 endosulfan이 거의 분해되지 않고 대부분 잔류하였다. 따라서 본 연구에서 분리한 endosulfan 분해균은 낮은 농도는 물론 $500 \mathrm{ppm}$ 의 높은 농도에서도 분해 속도가 느리기는 하나, 어느 정도의 분해능을 보였다. 그러나 $1,000 \mathrm{ppm}$ 이상의 매우 높은 농도의 endosulfan은 거의 분해하 지 못하였다 (Fig. 1).

\section{보조 탄소원 농도에 따른 endosulfan 분해능}

보조 탄소원의 농도에 따른 endosulfan 분해능을 측정하였 다. $100 \mathrm{ppm}$ 의 endosulfan이 함유된 YNB 배지에 보조 탄소원 인 yeast extract를 각각 $0 \%, 0.01 \%, 0.05 \%, 0.1 \%, 0.5 \%$ 가 되도록 첨가하여 조제한 후 분해균을 접종하여 배양하면서 시간에 따른 endosulfan 분해능을 측정 및 비교하였다. 보조 탄소원이 전혀 없는 경우 $(0 \%$ yeast extract), endosulfan의 분해가 매우 느려 관찰 기간 동안 (6주) 약 $20 \%$ 정도의 분해율을 보였다. 보조 탄소원을 첨가한 경우에는 초기 분해속도가 보조 탄소원 이 없는 경우와 비슷했으나 2주후부터 분해가 촉진되기 시작 하여, $0.5 \%$ 의 yeast extract를 첨가한 배지에서는 6 주후 관찰 기 약 $95 \%$ 의 endosulfan 분해율을 나타내었다 (Fig. 2). 보조 탄소원을 $0.01 \%, 0.05 \%, 0.1 \%$ 의 농도로 첨가한 경우에는 배양 


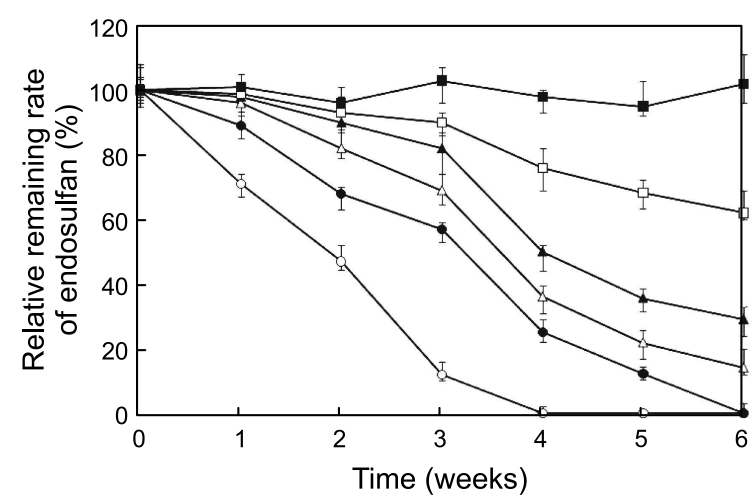

Fig. 1. Biodegradation of endosulfan by Serratia sp. K-1321. Cells were grown in YNB containing endosulfan. Endosulfan was determined by GC/MS analysis. $\bigcirc-\bigcirc, 10 \mathrm{ppm}$ endosulfan; - $50 \mathrm{ppm}$ endosulfan; $\triangle-\triangle, 100 \mathrm{ppm}$ endosulfan; $\boldsymbol{\Lambda}-\boldsymbol{\Lambda} ; 200 \mathrm{ppm}$ endosulfan; $\square-\square, 500 \mathrm{ppm}$ endosulfan; $\mathbf{\square} \mathbf{-}, 1,000 \mathrm{ppm}$ endosulfan.

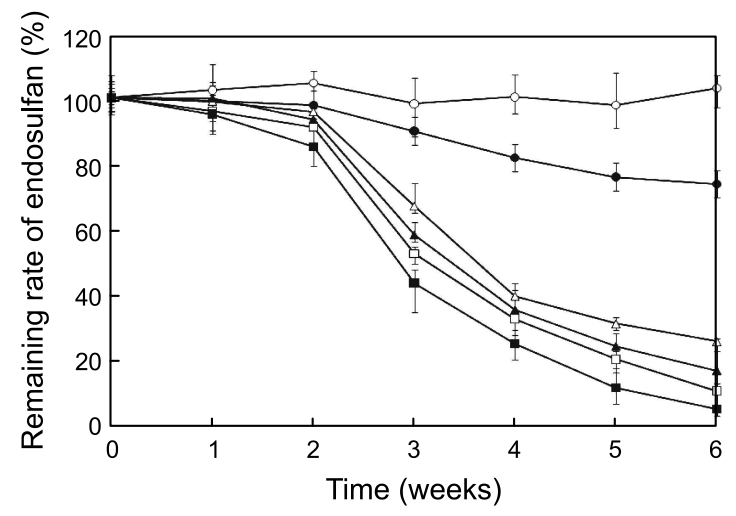

Fig. 2. Effect of an additional carbon source on endosulfan biodegradation by Serratia sp. K-1321. After inoculation, cells were cultivated at $25^{\circ} \mathrm{C}$ in YNB medium containing $100 \mathrm{ppm}$ endosulfan. $\bigcirc-\bigcirc$, control (no inoculation); $0 \%$ yeast extract; $\triangle-\triangle, 0.01 \%$ yeast extract; $\boldsymbol{\Delta}-\mathbf{\Delta}, 0.05 \%$ yeast extract; $\square-\square, 0.1 \%$ yeast extract; $\square-\square, 0.5 \%$ yeast extract.

6주후 각각 $70 \%, 80 \%, 85 \%$ 의 분해율을 보여, 근소한 차이이기 는 하나 보조 탄소원의 농도가 높은 배지에서 endosulfan의 분해가 비교적 빠른 속도로 일어났다 (Fig. 2). 이는 보조 탄소 원의 농도가 높을수록 분리균의 증식이 촉진되기 때문에 균의 증식과 더불어 endosulfan이 분해 (에너지 대사)가 이루어진 것으로 생각되어진다.

Endosulfan 분해균에 의한 토양에서의 endosulfan 분해 특성

Endosulfan 분해균 K-1321에 의한 토양에서의 endosulfan 분해능을 조사하였다. 그 결과, $50 \mathrm{ppm}$ endosulfan으로 오염시 킨 토양의 경우에는 6주에 endosulfan이 완전 분해되었다 (Fig. 3). $100 \mathrm{ppm}$ 의 endosulfan으로 오염시킨 토양에서는 6주후 약 $85 \%, 200 \mathrm{ppm}$ 으로 오염시킨 토양에서는 $75 \%$ 의 분해율이
나타났다. 그러나 $\mathrm{YNB}$ 배지에서와는 달리 $500 \mathrm{ppm}$ 의 endosulfan으로 오염시킨 토양에서는 endosulfan의 분해가 거 의 일어나지 않았는데 이는 $500 \mathrm{ppm}$ 의 endosulfan에 의한 균 증식 저해에 의한 것으로 생각된다 (Fig. 3).

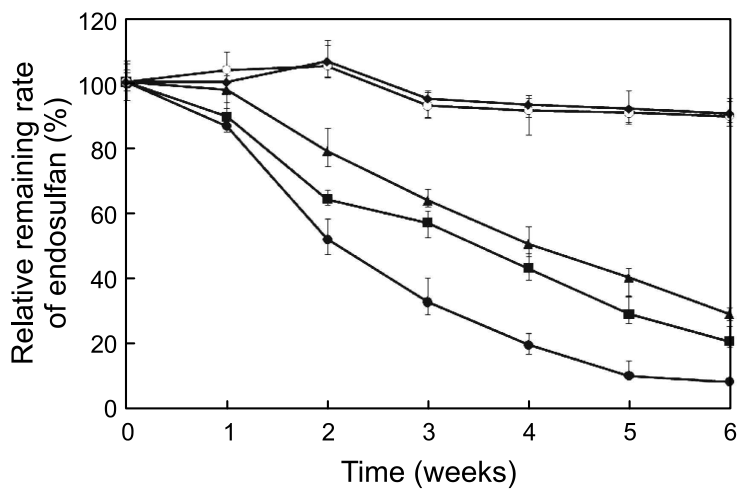

Fig. 3. Endosulfan bioaugmentation of endosulfan by Serratia sp. K-1321. Cells were grown in soil containing endosulfan. Endosulfan was determined by GC analysis. $\bigcirc-\bigcirc$, Control (no inoculation); - 0 , 50 ppm endosulfan; $\square-\square, 100$ ppm endosulfan; $\boldsymbol{\Delta}-\boldsymbol{\Delta}$; 200 ppm endosulfan; $\boldsymbol{\diamond} \boldsymbol{\diamond}, 500$ ppm endosulfan.

Endosulfan 분해균 K-1321의 endosulfan 분해능을 조사한 결과를 종합해 보면, $200 \mathrm{ppm}$ 이하의 농도에서는 배양배지에서 보다 토양에서 더 빠른 속도로 endosulfan이 분해되는 양상을 보였으나 $500 \mathrm{ppm}$ 의 농도에서는 토양 중의 endosulfan은 분해 하지 못하는 것으로 조사되었다. 또한 각 농도의 토양 실험구에 서 endosulfan 분해균을 접종시키지 않은 대조구 (control; no inoculation)에서도 $10 \%$ 미만의 미량이지만 endosulfan이 상당 히 느린 속도로 감소하는 경향을 보였는데, 이러한 결과는 $\mathrm{Kim}$ et al. (2008)의 보고와 같이 endosulfan이 토양에 흡착되거 나 공기 중으로 휘발하였기 때문으로 생각된다.

분리균주 $\mathrm{K}-1321$ 의 endosulfan 분해 경로

Endosulfan의 생물학적 분해에 대하여 많은 연구가 보고되 고 있으며 (Fig. 4), 다양한 미생물에 의해 분해되는 것으로 알려져 있다 (Sutherland et al., 2002a; Sutherland et al., 2002b; Hussain et al., 2007). Lee et al. (2006)은 Pseudomonas sp. KS-2P 에 의해 endosulfan 및 endosulfan sulfate가 분해된다고 보고하 였으며, Kwon et al. (2003)은 Klebsiella pneumoniae KE-1이, Surtherland et al. (2002a)은 Mycobacterium strain이 endosulfan sulfate를 생성하지 않고 endosulfan을 분해한다고 보고하였다. 또한 Kwon et al. (2005)은 Klebsiella oxytoca KE-8이 endosulfan sulfate를 분해한다고 보고하였고, Lee et al. (2003)은 Anabaena sp.가 endosulfan을 분해하여 endosulfan을 endosulfan sulfate와 알려지지 않은 물질을 생성한다고 보고하였다. Shin et al. (2008)은 Bacillus sp. E64-2가 endosulfan을 endosulfan diol로, Awasthi et al. (2003)은 Bacillus strain이 endosulfan을 endosulfan diol과 endosulfan lactone으로 분해한다고 보고하였 


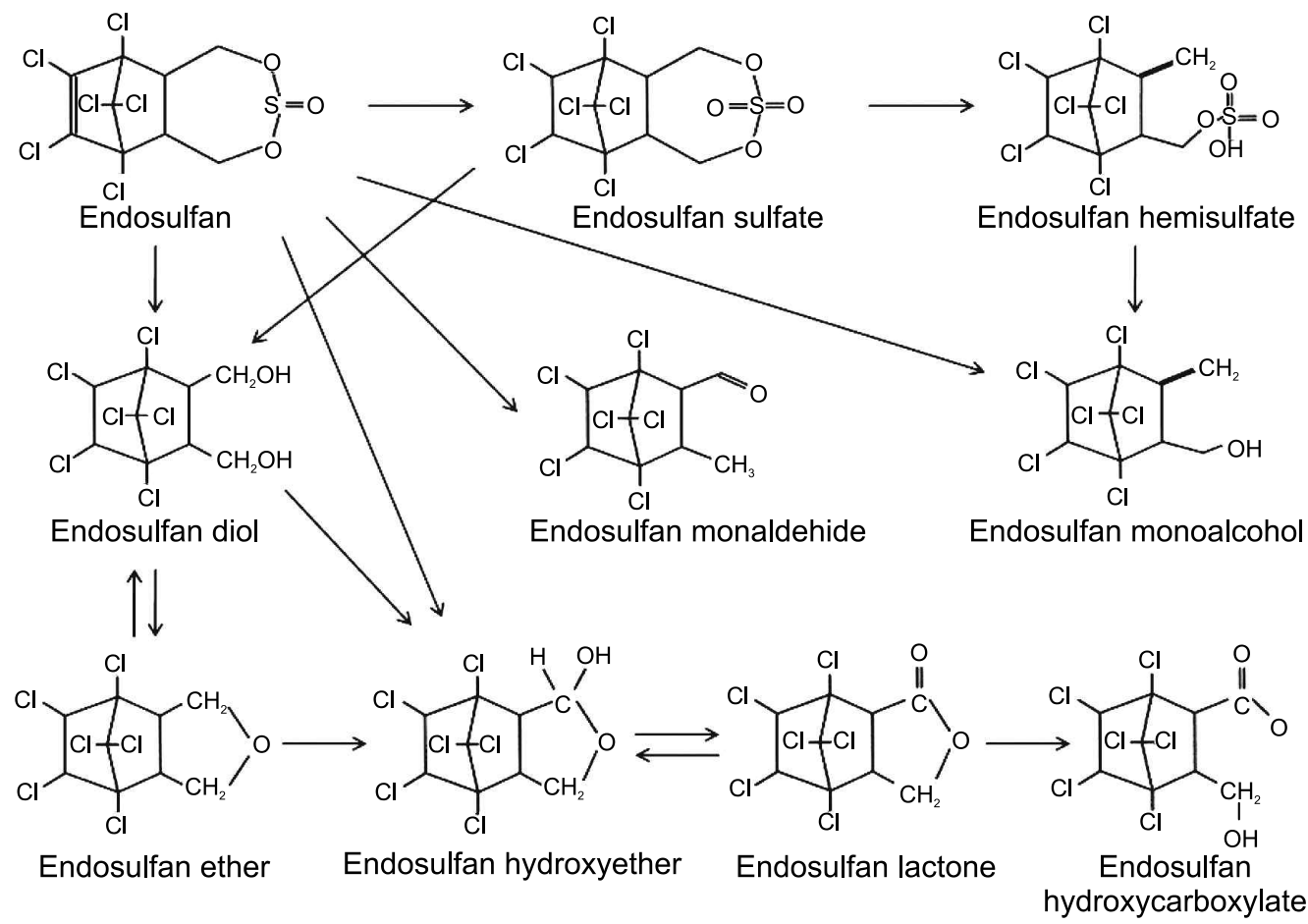

Fig. 4. Proposed metabolic pathways of endosulfan (Awasthi et al., 2003; Hussain et al., 2007; Kwon et al., 2005; Lee et al., 2003; Lee et al., 2006; Siddique et al., 2003; Sutherland et al., 2002a; Sutherland et al., 2002b).

(A)

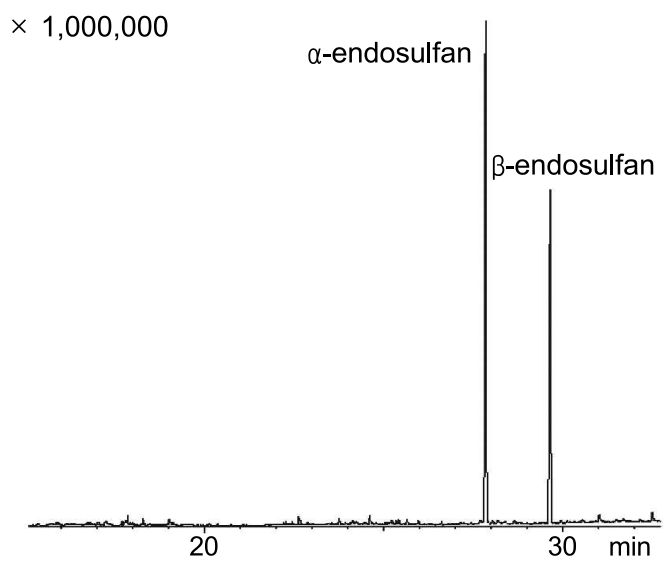

(B)

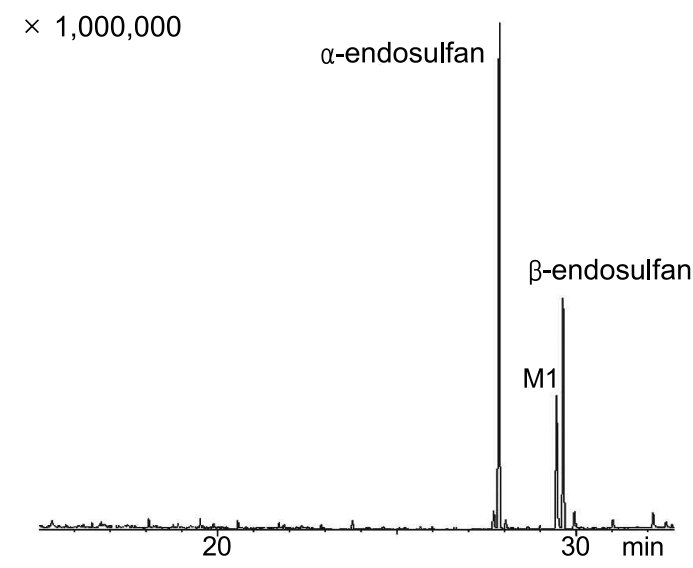

(C)

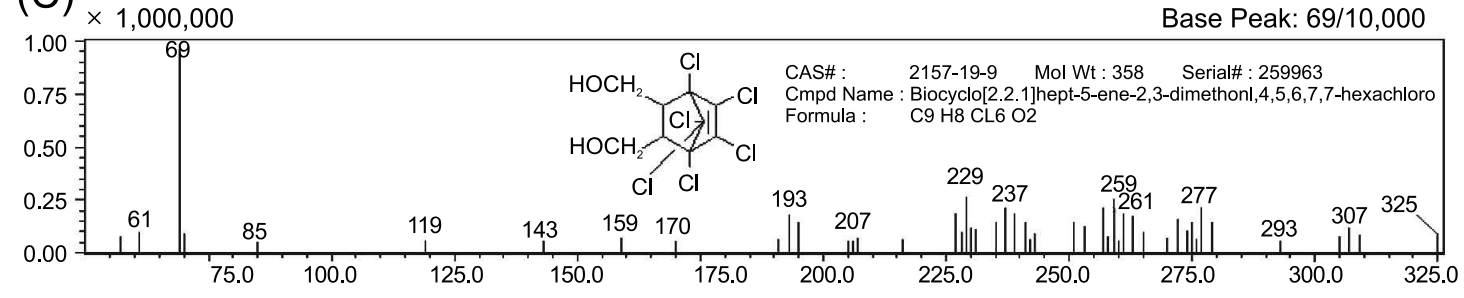

Fig. 5. GC/MS profile and mass spectra of endosulfan and its metabolites. Cells were grown in YNB medium containing $100 \mathrm{ppm}$ endosulfan. After 4 weeks incubation, GC/MS analysis was conducted. A, GC/MS profile of endosulfan; B, GC/MS profile of metabolites; C, Mass spectra of the metabolite I (MI). 
<smiles>O=S1(=O)OCC2C(CO1)C1(Cl)C(Cl)=C(Cl)C2(Cl)C1(Cl)Cl</smiles>

Endosulfan<smiles>CCC1C(Cl)C2(Cl)C(Cl)C(CO)C1(Cl)C2CO</smiles>

Endosulfan diol

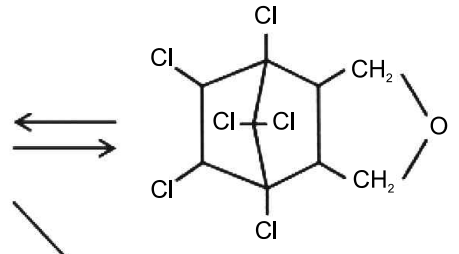

Endosulfan ether

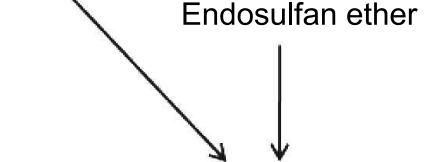<smiles>O=C(O)C1C(CO)C2(Cl)C(Cl)C(Cl)C1(Cl)C2(Cl)Cl</smiles><smiles>CCC</smiles><smiles>COC(=O)C1C(C)C2(Cl)C(Cl)C(Cl)C1(Cl)C2(Cl)Cl</smiles>

Endosulfan lactone<smiles>C[C@@H]1[C@H]([C@@H](O)CO)[C@@]2(Cl)[C@@H](Cl)[C@H](Cl)[C@]1(Cl)C2(Cl)Cl</smiles>

Endosulfan hydroxyether hydroxycarboxylate

Fig. 6. Proposed pathway of endosulfan biodegradation by Serratia sp. K-1321.

는데, 일반적으로 토양환경 중에서는 endosulfan sulfate가 주 요 대사산물로 생성되기 때문에 문제가 되고 있다 (Rao and Murty, 1980; Shin et al., 2008; Cho, 2010).

본 연구에서 분리한 endosulfan 분해균주 $\mathrm{K}-1321$ 에 의한 endosulfan 분해 산물 을 GC/MS로 분석한 결과, endosulfan diol이 검출되었으며, 시간에 따라 그 양이 증가함을 확인하였 다 (Fig. 5). 따라서 Serratia sp. K-1321은 endosulfan을 endosulfan diol로 분해하여 endosulfan diol이 endosulfan ether 및 endosulfan lactone을 거쳐 endosulfan hydroycarboylate로 분해하는 경로를 따르는 것으로 추정하였다 (Fig. 6).

본 연구에서 보고한 바와 같이 높은 독성을 가지며 환경에 서 잔류성이 큰 난분해성 화합물을 잘 분해할 수 있는 미생물 을 선발하고 그 특성을 잘 이용한다면, 이러한 화합물이 축적 되어 있는 생태계의 복원뿐만 아니라 궁극적으로 이 화학물질 이 잔류한 환경에서 생산된 농·수산물에 대한 안전성의 보장 에도 기여할 수 있을 것으로 여겨지며, endosulfan 이외의 난분 해성 유기오염물질의 분해 및 제거를 위한 기초 자료로 이용 될 수 있을 것으로 판단된다.

$$
\text { 사 사 }
$$

“이 논문은 2010학년도 부경대학교 연구년 교수 지원사업 에 의하여 연구되었음 (PS-2010-011)".

\section{참고문헌}

Awasthi N, Singh AK, Jain RK, Khangarot BS and Kumar A. 2003. Degradation and detoxification of endosulfan isomers by a defined co-culture of two
Bacillus strain, Appl Microbiol Biotechnol 62, 279-283.

Beauvais SL, Silva MH and Powell S. 2010. Human health risk assessment of endosulfan: III. Occupational handler exposure and risk. Regul Toxicol Pharmacol $56,28-37$.

Berns KI and Thomas CA. 1965. Isolation of the high molecular DNA from Haemophilus influenzae. J Mol Biol 11, 476-490.

Cho KB. 2010. Residual Characteristics of endosulfan in Busan and Gimhae Farmland. M.D. Thesis, Dong-A University, Busan, Korea.

Chung RP, Choi MK, Yeo HG and Chun MY. 2001. Seasonal variations in the concentration of persistent organochlorine pesticides in atmosphere. Kor $\mathrm{J}$ Environ Agric 20, 79-85

Chaudhuri K, Selvaraj S and Pal AK. 1999. Studies on the genotocixity of endosulfan in bacterial systems. Mutat Res 439, 63-67.

Dunbar J, Ticknor LO and Kuske CR. 2000. Assessment of microbial diversity in four South-western United States soils by $16 \mathrm{~S}$ rRNA gene terminal restriction fragment analysis. Appl Environ Microbiol 66, 2943-2950.

Fujii K, Urano N, Kimura S, Nomura Y and Karube I. 2000. Microbial degradation of nonylphenol in some aquatic environments. Fish Sci 66, 44-48.

Guerin TF. 2001. A biological loss of endosulfan and 
related chlorinated organic compounds form aqueous systems in the presence and absence of oxygen. Environ Pollut 115, 219-230.

Ha KT, Park SK, Cho TH, Han CH, Kim SD, Lee KA, Kim SJ, Jang JI, Jo HB and Choi BH. 2009. Monitoring on endocrine disruptors in commercial agricultural products in the northern area of Seoul (2007). J Food Hyg Safety 24, 136-142.

Harner T, Shoeib M, Kozma M, Gobas FAPC and Li SM. 2005. Hexachlorocyclohexanes and endosulfans in urban, rural, and high altitude air samples in the fraser valley, british columbia: Evidence for trans-pacific transport. Environ Sci Technol 39, 724-731.

Hussain S, Arshad M, Saleem M and Khalid A. 2007. Biodegradation of alpha- and beta-endosulfan by soil bacteria. Biodegradation 18, 731-740.

Kim SD, Kim BS, Park SK, Kim MY, Cho TH, Han CH, Jo HB and Choi BH. 2007. A Study of current status on pesticide residues in commercial dried agricultural products. Kor J Food Sci Technol 39, 114-121.

Kim SK, Cho SH and Cho NS. 2004a. A case of endosulfan intoxication occurring in groups. Kor Soc Emerg Med 5, 409-412.

Kim TK, Kim JE, Kim TH, Shin HS, Kwon OK, Kim JD and Lim SJ. 2008. Chemical remediation of soils contaminated with endosulfan organochlorine insecticide. Kor J Environ Agric 2, 75-89.

Kim YG, Kim TG, Park SS, Heo NC and Hong SS. 2000. A study on residual pesticides in commercial fruits and vegetables. Kor J Food Sci Technol 32, 763-771.

Kim YM, Park K, Joo GJ, Jeong EM, Kim JE and Rhee IK. 2004b. Glutathione-dependent biotransformation of the fungicide chlorothalonil. J Agric Food Chem 52, 4192-4196.

Krieg NR and Holt JG. 1984. Bergey's Manual of Systematic Bacteriology Vol 1. In: Genus VIII. Grimont PAD and Grimont F, eds. Williams \& Wilkins, Baltimore, U.S.A., 477-484.

Kwon GS, Kim JE, Kim TK, Sohn HY, Koh SC, Shin KS and Kim DG. 2003. Klebsiella pneumoniae KE-1 degrades endosulfan without formation of the toxic metabolite, endosulfan sulfate. FEMS Microbiol Lett 215, 255-259.

Kwon GS, Sohn HY, Shin KS, Kim EJ and Seo BI. 2005. Biodegradation of the organochlorine insecticide, endosulfan, and the toxic metabolite, endosulfan sulfate, by Klebsiella oxytoca KE-8., Appl Microbiol
Biotechnol 67, 845-850.

Laabs V, Amelung W, Pinto AA, Wantzen M, da Silva CJ and Zech W. 2002. Pesticides in surface water, sediment, and rainfall of the northeastern Pantanal basin, Brasil. J Environ Qual 31, 1636-1648.

Lee JB, Sohn HY, Shin KS, Jo MS, Kim JE, Lee SW, Shin JW, Kum EJ and Kwon GS. 2006. Isolation of a soil bacterium capable of biodegradation and detoxification of endosulfan and endosulfan sulfate. J Agric Food Chem 54, 8824-8828.

Lee SE, Kim JS, Kennedy IR, Park JW, Kwon GS, Koh SC and Kim JE. 2003. Biotransformation of an organochlorine insecticide, endosulfan, by Anabaena species. J Agric Food Chem 51, 1336-1340.

Lo'pez-Blanco MC, Cancho-Grande B, Simal-Ga'ndara J, Lo'pez-Periago $\mathrm{E}$ and Arias-Estevez $\mathrm{M}$. 2005.Transport of commercial endosulfan through a column of aggregated vineyard soil by a water flux simulating field conditions. J Agric Food Chem 53, 6798-6743.

Park KR, Jung YS and Rim H. 2008. A case of endosulfan intoxication with pulmonary embolism. Kor Assoc Intern Med 74, S250-S253.

Park SK, Ha KT, Kim SD, Kim SJ, Lee YJ, Lee KA, Jang JI, Jeoung SS, Song BY, Jo SJ, Jo HB, Choi BH and Kim MY. 2009. Survey on pesticide residues in commercial agricultural products in the northern area of Seoul. J Food Hyg Safety 24, 27-37.

Rao DMR and Murty AS. 1980. Persistence of endosulfan in soils. J Agric Food Chem 28, 1099-1101.

Shin JH, Kwak YY, Kim WC, So JH, Shin HS, Park JW, Kim TH, Kim JE and Rhee IK. 2008. Isolation of endosulfan degrading bacteria and their degradation characteristics. Kor J Environ Agric 27, 292-297.

Siddique T, Okeke BC, Arshad M and Frankenberger WT. 2003. Enrichment and isolation of endosulfan-degrading microorganisms. J Environ Qual 32, 47-54.

Silva MH and Beauvais SL. 2010. Human health risk assessment of endosulfan: I . Toxicology and hazard identification. Regul Toxicol Pharmacol 56, 4-17.

Silva MH and Carr WC. 2010. Human health risk assessment of endosulfan: $\Pi$. Dietary exposure assessment. Regul Toxicol Pharmacol 56, 18-27.

Sutherland TD, Horne I, Harcourt RL, Russell RJ and Oakeshott JG. 2002a. Isolation and characterization of a Mycobacterium strain that metabolizes the insecticide endosulfan. J Appl Microbiol 93, 
380-389.

Sutherland TD, Horne I, Russell RJ and Oakeshott JG. 2002b. Gene cloning and molecular characterization of a two-enzyme system catalyzing the oxidative detoxification of beta-endosulfan. Appl Environ Microbiol 68, 6237-6245.

Usha S and Harikrishnan VR. 2004. Endosulfan, Thanal,
Kerala, India, 3-4.

2010년 12월 11일 접수

2011년 1월 31일 수정

2011년 6월 8일 수리 